\title{
DOWNSIDE CAPM: The CASE OF SOUTH AfRICA
}

\author{
Kwasi Okyere-Boakye* \\ University of the Witwatersrand
}

Received: September 2015

\author{
Brandon 0'Malley" \\ University of the Witwatersrand
}

Accepted: February 2016

\begin{abstract}
Beta and the capital asset pricing model have traditionally been the preferred measures of risk. However, there is growing literature against the use of the capital asset pricing model to determine the cost of equity in markets, such as emerging markets, where investors display mean-semivariance behaviour and, where share returns are non-normal and asymmetric. Downside risk measures such as semideviation, downside beta and the downside capital asset pricing model have been found to be plausible alternate measures of risk. This study investigates empirically the relationship between risk and return in a downside risk framework and a regular risk framework using returns on companies listed on the JSE Securities Exchange. The empirical evidence from this study indicates that while downside beta and semideviation significantly explain the variation in returns, they do not support them as being more appropriate measures of risk over beta and standard deviation.
\end{abstract}

Keywords

Beta, capital asset pricing model, cost of equity, downside beta, downside risk, semideviation

*Mrs K Okyere-Boakye is a senior lecturer in the Department of Accountancy at the University of the Witwatersrand, South Africa. [Kwasi.Okyere-Boakye@wits.ac.za]

"Mr B O'Malley is a Master's student in the Department of Accountancy at the University of the Witwatersrand, South Africa. 


\section{INTRODUCTION}

The evaluation of projects for investment and the valuation of companies for acquisition enable investors to allocate resources efficiently to value-creating assets. The value of a project or company is determined by discounting forecasted cash flows at an appropriate discount rate which represents the risk associated with the investment. The measure of risk and factors that affect share returns in developed markets has been challenging (Estrada J. , The Cost of Equity in Emerging Markets: A Downside Risk Approach (II), 2001). While the capital asset pricing model (CAPM) has conventionally been used in developed markets to determine required returns on investments, it still raises concerns as to whether beta, the measure of systematic risk, is the most appropriate measure of risk.

Estimating risk in developed markets is different from estimating risk in emerging markets (Estrada J. , The Cost of Equity in Emerging Markets: A Downside Risk Approach, 2000) as the investment community sees emerging markets as more risky and this makes the question of appropriate risk factors more complex and important: this has stimulated more interest in trying to discover the factors which best explain the cross-section of share returns in emerging markets. Emerging markets have attracted much attention and investors must ensure that they measure risk accurately.

Concerns regarding the use of the CAPM are twofold. Firstly, beta, which is the model's measure of risk, is the equilibrium achieved when investors display mean-variance behaviour (MVB); that is, the maximisation of investor utility depends only on the mean and variance of portfolio returns (Estrada J. , Mean-Semi Variance Behavior: An Alternative Behavioral Model, 2004). Investors can also be considered to display mean-semivariance behaviour (MSB) (Estrada J. , Mean-Semi Variance Behavior: An Alternative Behavioral Model, 2004) and in this form the beta may not be appropriate. Secondly, beta is appropriate when returns in the market are symmetrical and normally distributed. Arguments have been submitted to suggest that returns in emerging markets are asymmetrical and non-normal thus raising the question of whether there are more appropriate risk measures: this is further supported by the low correlation between beta and share returns in emerging markets which leads to required returns which do not reward investors sufficiently for the level of risk borne (Estrada J., The Cost of Equity in Emerging Markets: A Downside Risk Approach, 2000).

As a result, attention is turning to downside risk measures in search of more appropriate risk measures in asymmetric markets. While the idea of downside risk was first introduced by Markowitz in 1959 through the development of the semideviation, numerous research reports have proposed more advanced models from an MSB perspective. The downside CAPM (D-CAPM), which applies downside beta as the measure of risk, is the suggested equilibrium model from an MSB perspective. This framework, through which this model was developed, was introduced by Hogan and Warren (1974), Bawa and Lindenberg (1977) and Harlow and Rao (1989) who all proposed CAPM-like models based on downside risk measures. After Estrada (2000) and (2001) reported the superiority of downside risk measures over mean-variance risk measures in explaining cross sectional share returns in emerging markets, he modified prior MSB consistent forms of the CAPM and proposed an alternate measure of risk, the downside beta and an alternate pricing model, the downside CAPM or D-CAPM (Estrada J. , 2002b).

The D-CAPM proposed by Estrada is the focus of this paper. The strength of this pricing model, along with other risk measures, has subsequently been researched in studies, including: Estrada (2002a) on internet companies; Mamoghlia and Daboussi (2008) on hedge funds; Artavanis, 
Diacogiannis and Mylonakis (2010) on the London Stock Exchange and the Paris Stock Exchange; and Cwynar and Kazmierkiewicz (2010) on the Warsaw Stock Exchange. They conclude that downside beta measures cross-sectional returns in asymmetrical markets with greater accuracy than the standard beta. Furthermore, they report that there are significant differences between required returns from the CAPM and the D-CAPM that should not be ignored. These studies will be discussed in more detail later in this paper.

The contribution of this paper is to investigate empirically, using cross-sectional return on companies listed on the South African JSE Securities Exchange (JSE), whether the semi-deviation and the downside beta are superior in explaining expected returns as compared to the standard deviation and regular beta. This study modifies the methodology of Estrada (2002b).

The remainder of the paper is organised as follows. Section 2 discusses prior literature on the appropriateness of downside risk measures. Section 3 reports and discusses the empirical evidence and a discussion of the findings, which clearly supports downside beta in a South African context. Finally, Section 4 contains concluding remarks. The appendix concludes the article.

\section{PRIOR LITERATURE}

A worthwhile starting point in the risk-return discourse is Markowitz's ground-breaking study on modern portfolio theory in 1952 (later published as a book in 1959) which remains the cornerstone of investment analysis today. In this study, Markowitz submits that investors maximise their utility through a risk and expected return framework. Levy and Markowitz (1979) report that expected utility is maximised with mean-variance efficient portfolios if their distributions are normal and symmetric; thus investors exhibit mean-variance behaviour (MVB). This frame was further validated more recently in Estrada (2004). Using MVB, William Sharpe (1964) developed an equilibrium pricing model which is the standard form of the CAPM. Beta is the measure of systematic risk in this model: it measures the sensitivity of share return variance to the market return variance.

In its early years empirical tests on the CAPM proved that there is a linear relationship between portfolio returns and beta. The model, however, received criticism from the early 1980's, questioning its efficiency (Raei, Ahmadinia, \& Hasbaei, 2011). Questions were raised specifically about the stability of beta and the linear relationship between beta and asset returns. Markowitz (1952) gave a hint that there might be other contenders to the mean-variance framework. In Markowitz (1959), the semi-variance, a downside risk measure, is proposed as a risk measure and it is further given support as being "more plausible than variance as a measure of risk, since it is concerned only with adverse deviations" (Markowitz, Foundations of Portfolio Theory, 1991). The semideviation, which is the square root of semi-variance is defined as:

$$
S=\sqrt{(1 / T) \sum_{t=1}^{T} \operatorname{Min}\left[\left(R_{t}-B\right), 0\right]^{2}}
$$

where $R$ denotres returns, $t$ indexes time, $T$ is the number of returns in the sample. $B$ represents the return on a chosen benchmark which may be independent of the choice of portfolio so that returns above $B$ are not relevant, but returns below are given weight. 
Hogan and Warren (1974) extended the body of research on downside risk techniques by developing the expected value-semivariance model, or $\varepsilon-S$ model. They developed the ES-CAPM model, which substitutes beta with their version of a downside beta based on Markowitz's semivariance and a different definition of cosemivariance. Their cosemivariance is given by

$$
\operatorname{Cosemivar}_{R F}\left(R_{M}, R_{i}\right)=\sum\left\{\left(R_{i}-R_{F}\right) \cdot \operatorname{Min}\left[\left(R_{M}-R_{F}\right), 0\right]\right\}
$$

where $R_{M}$ is the return on the market and $R_{F}$ is the benchmark return.

They argue that rational investors would choose portfolios that minimize the semivariance for a given expected return, or maximize the expected return for a given semivariance. The ES-CAPM model, therefore, allows the investor to structure his portfolio in such a way that only downside risk is minimized which is in contrast to the variance which, when minimized, does not differentiate between extreme gains and extreme losses. Hogan and Warren (1974) proved that the capital market line (CML) can also be derived using the $\varepsilon-S$ model and, when combined with an investor's utility functions, the efficient frontier can be developed.

Bawa and Lindenberg (1977) developed their theory on the mean-lower partial moment (MLPM) which is the generalised form of the Hogan-Warren framework. Similar to the Hogan-Warren framework, the Bawa-Lindenberg framework defines the risk free rate as the benchmark return. They conclude that the CAPM is a specialised case of MLPM and that their model is guaranteed to be as strong as the CAPM.

Finally, Harlow and Rao (1989) expanded the MLPM by allowing the investor to choose any arbitrary benchmark return. The previous frameworks i.e. Hogan-Warren and Bawa-Lindenberg were made to be specialised cases of the Harlow-Rao framework. Empirical tests could not reject their version of MLPM as a reliable pricing model, while the CAPM can be rejected (Harlow \& Rao, 1989).

By assuming a US-based internationally diversified investor and using the entire database of Morgan Stanley Capital International (MSCl) which covers 28 emerging markets, Estrada (2000) studies the explanatory power of 9 risk factors regressed against cross-sectional returns. The risk measures include 3 semideviation measures where the benchmarks are set to be the mean of returns, risk free rate and zero, respectively. His study finds support for the validity of downside risk measures in addition to standard deviation and idiosyncratic risk. Of the three semideivations, only the one with the mean set as the benchmark was significant. Beta was not significant. Estrada's explanation of the results is that emerging markets are not fully integrated with the world market making beta an inappropriate measure of risk. Stulz (1995), as cited by Estrada (2000), concluded that the required return in fully integrated markets is best measured by beta, but, for emerging markets which are considered to be segmented the standard deviation is appropriate. Hence the application of a local CAPM in segmented markets would be appropriate and a global CAPM should be applied in integrated markets. He concludes his study by stating that semideviation can be applied at the country, as well as at the company, level.

Estrada (2001), turned his attention to industry betas. He finds that industry betas and downside risk with respect to the mean are significantly related to the cross-section of returns.

The introduction of the semi-variance suggested that investors may display mean-semivariance behaviour (MSB). Estrada (2004) evaluates whether MSB is a correct criterion and concludes that it yields a level of utility that is highly correlated with an investor's expected utility; investors can 
maximise their utility by investing in mean-semivariance efficient portfolios, especially in emerging markets.

Estrada (2002a) submits that internet companies have a short history, are very volatile, have low correlation with the market, exhibit skewed return distributions and so are similar to emerging markets. He finds that beta, standard deviation and semideviation are all significant. However, semideviation has twice and one-half the explanatory power of beta and standard deviation respectively. Practical arguments submitted by Estrada (2002a) in support of the semivariance are 1) investors only dislike downside volatility and not upside volatility, 2) semideviation is more useful than standard deviation when return distributions are non-normal and asymmetric and 3) semideviation combines return variance and skewness into one factor which can be used to estimate required returns.

Estrada (2002b) proposes and alternate measure of risk (the downside beta) and an alternate pricing model referred to as the downside CAPM (D-CAPM). The downside beta is the ratio of cosemivariance with the market and semideviation of the market. Both of these inputs use the asset's arithmetic mean as the benchmark return. Hence, obtaining asset i's downside beta is given by

$$
\beta_{i}^{D}=\frac{\operatorname{Cosemivar}\left(R_{i,} R_{M}\right)}{\operatorname{Semivar}\left(R_{M}\right)}=\frac{\sum\left\{\operatorname{Min}\left[\left(R_{i,}-\mu_{i}\right), 0\right] \operatorname{Min}\left[\left(R_{M}-\mu_{M}\right), 0\right]\right\}}{\sum\left\{\operatorname{Min}\left[\left(R_{M},-\mu_{M}\right), 0\right]^{2}\right\}}
$$

The downside beta now replaces the standard beta in the CAPM to give the D-CAPM which is given by

$$
E\left(R_{i}^{D}\right)=R_{f}+\beta_{i}^{D}\left(R_{m}-R_{f}\right)
$$

Subsequently, the downside beta has been the subject of various studies that have validated the appropriateness of the risk measure when returns are asymmetric and non-normal. These supporting studies include Artavanis, Diacogiannis \& Mylonakis (2010), Cwynar \& Kazmierkiewicz (2010), and Mamoghlia \& Daboussi (2010). According to Mamoghlia and Daboussi (2008), many studies showed pronounced return asymmetry and non-normality in the hedge fund universe. Their findings indicate that capital asset pricing models, especially the D-CAPM described the returns on hedge funds much better. Artavanis, Diacogiannis and Mylonakis (2010) in their study on the London Stock Exchange and the Paris Stock Exchange found that more often than not the downside risk measures are equivalent or are better for explaining cross-sectional asset returns that mean-variance consistent risk measures.

A study on the automobile manufacturing companies listed on the Tehran Stock Exchange proved the superiority of D-CAPM over CAPM to determine the expected return rate (Nikoomaram, 2010). Finally, Cwynar and Kazmierkiewicz (2010) find results on the Warsaw Stock Exchange which are consistent with prior empirical evidence. They conclude that the Bawa-Lindenberg model produced the best results when applied to the Polish market. 


\section{DATA AND RESULTS}

\subsection{The Model}

The D-CAPM framework is explored in this article. It is as easy as the CAPM. As discussed in the literature it is grounded in modern portfolio theory and it measures the downside risk which concerns investors.

The CAPM and the D-CAPM are consistent in measuring required return in that they compensate the investor for expected loss in purchasing power and for bearing systematic risk; the former is the risk free rate and the latter the risk premium. The study assumes a locally diversified investor, instead of an internationally diversified investor. Hence the risk free rate compensates the investor for loss of purchasing power in South Africa and the risk premium is compensation for investing in a well-diversified South African market portfolio. In symbols:

$$
E\left(R_{i}\right)=R_{f}+R M_{i}\left(R P_{S A}\right)
$$

where $E\left(R_{i}\right)$ is the expected or required return, $R_{f}$ is the South African risk free rate, $R M_{i}$ is the risk measure, $R P_{S A}$ is the South African risk premium and $i$ indexes the companies in the sample.

The benchmark risk free rate is the annual yield on a 10 -year South African government bond. The JSE All Share Index (ALSI) is market portfolio. The risk premium is the difference between the annual arithmetic mean return on ALSI measured over a 108-year historic period and the arithmetic mean return on the 10 year government bond measured over the same period. This is consistent with practice in South Africa. These inputs are recalculated annually in the study, allowing the risk free rate and the risk premium to vary over time. Refer to TABLE A-3 in the appendix for the estimated values applied in the study. This is a major departure from prior studies; it allows the study to capture changes in shares returns and market risk over time.

Four risk variables are considered in the study. The beta and standard deviation are selected from an MVB framework; downside beta (equation 3) and semideviation (equation 1) are selected from the MSB framework. Beta is the variance of asset is returns with respect to the variance of the ALSI's returns. Downside beta is calculated with respect to the mean return on the ALSI; and semideviation is calculated with respect to the mean return on asset $i . R M_{i}$ is the ratio of asset is risk variable to that of the market.

\subsection{Data}

The study examines whether the risk variables under the MSB have more explanatory power than risk variables from an MVB framework. Can downside beta and semideviation explain the crosssection of share returns over time better than beta and standard deviation can?

To answer this question data is obtained from two databases. Prices of the ALSI are obtained from the Global Financial Database as it provides the longest history of monthly pricing going as far back as January 1910 which permits the calculation of the risk premium over a 108 -year period.

For the risk analysis on companies, the period from 1999 to 2014 (16 years) is the period of interest. For a company to qualify as a sample in a given year, the company should have returns going back at least 60 months. Suspended companies were excluded from the sample. This sample criterion introduces survival bias. However this is unlikely to produce a systematic bias on the 
results. The final sample included 311 companies representing 3152 company years. The sample is an unbalanced panel data set.

Monthly share prices for companies listed during this period were obtained from the InetBFA Database. Annual returns for each company accounted for capital gains as well as dividends and were calculated as follows:

$$
R_{i t}=\ln \left(\frac{P_{t}+d_{t}}{P_{t-1}}\right)
$$

where $R_{i t}$ is the average return for company $i$ in year $t, P_{t}$ is the price in month $\mathrm{n}$ of year $\mathrm{t}, P_{t-1}$ is the previous month's closing price, $d_{t}$ is the dividend declared.

Beta and downside beta are calculated over a 60 months period.

\subsection{Results}

The central argument on which the validity of DCAPM and downside risk measures sits is nonnormal and asymmetric returns. The report begins the discussion of results with a brief analysis of the distribution of returns across the sample. TABLE 1 reports the results of tests for skewness, kurtosis and normality. These results indicate that returns for the sample are significantly skewed for all years individually and collectively, with the exception of 2001. TABLE A-1 in the appendix indicates that for a majority of the years including the overall sample the returns are positively skewed.

An inspection of a histogram of mean returns (refer to Exhibit A-2 in appendix) indicates that the violation of symmetry is not extreme. The plausibility of the downside risk measures is linked to the existence of skewed distributions of returns. Hence this mild violation of symmetry could affect the appeal of the downside risk framework.

By examining the Jacque-Bera probability in the last column of TABLE 1 , it is evident that the returns for all the years are not normally distributed, except in 2001. The results are consistent with the findings of Jefferis and Smith (2004) and, Mamoghlia and Daboussi (2010). This gives some preliminary backing to the downside risk measures. TABLE A-2 provides additional descriptive statistics.

TABLE 1: Jacque-Bera test for normality

\begin{tabular}{ccccc}
\hline Year & Obs & $\operatorname{Pr}$ (Skew) & $\operatorname{Pr}$ (Kurt) & Prob>chi $^{2}$ \\
\hline 1999 & 113 & 0.03 & 0.01 & 0.01 \\
2000 & 124 & 0.00 & 0.00 & 0.00 \\
2001 & 135 & 0.05 & 0.45 & 0.11 \\
2002 & 145 & 0.00 & 0.00 & 0.00 \\
2003 & 167 & 0.00 & 0.00 & 0.00 \\
2004 & 176 & 0.00 & 0.00 & 0.00 \\
2005 & 184 & 0.00 & 0.00 & 0.00 \\
2006 & 189 & 0.00 & 0.00 & 0.00 \\
\hline
\end{tabular}




\begin{tabular}{ccccc}
\hline Year & Obs & $\operatorname{Pr}$ (Skew) & $\operatorname{Pr}$ (Kurt) & Probrchi $^{2}$ \\
\hline 2007 & 195 & 0.00 & 0.00 & 0.00 \\
2008 & 198 & 0.00 & 0.00 & 0.00 \\
2009 & 206 & 0.00 & 0.00 & 0.00 \\
2010 & 218 & 0.00 & 0.00 & 0.00 \\
2011 & 240 & 0.00 & 0.00 & 0.00 \\
2012 & 279 & 0.35 & 0.00 & 0.00 \\
2013 & 290 & 0.00 & 0.00 & 0.00 \\
2014 & 293 & 0.00 & 0.00 & 0.00 \\
All & 3152 & 0.00 & 0.00 & 0.00 \\
\hline
\end{tabular}

Source: Authors' analysis

Obs, observations; $\operatorname{Pr}$ (Skew), probability of test for skewness; $\operatorname{Pr}\left(\right.$ Kurt), probability of test for kurtosis; Prob>chi ${ }^{2}$, probability of test for normality using Jacque-Bera test.

A correlation matrix containing mean returns and the four risk variables under consideration is reported in TABLE 2. As can be seen from the table, all the risk variables are significantly correlated to the mean returns and to each other. However, the correlations with mean returns are very low. Standard deviation has a correlation of $48 \%$ with mean returns which is almost double the correlations between the other variables and mean returns. Beta and standard deviation outperform the downside risk measures.

TABLE 2: Cross-sectional analysis - correlation matrix

\begin{tabular}{lccccc}
\hline & MR & $\boldsymbol{\beta}$ & $\boldsymbol{\sigma}$ & $\boldsymbol{\beta}_{\boldsymbol{\mu}}^{D}$ & $\Sigma_{\boldsymbol{\mu}}$ \\
\hline MR & 1.00 & & & & \\
$\beta$ & $0.29 \star$ & 1.00 & & & \\
$\sigma$ & $0.48^{\star}$ & $0.74^{\star}$ & 1.00 & 1.00 & \\
$\beta_{\mu}^{D}$ & $0.28^{\star}$ & $0.35^{\star}$ & $0.61^{\star}$ & $0.72 *$ & 1.00 \\
$\Sigma_{\mu}$ & $0.25^{\star}$ & $0.35^{\star}$ & $0.56^{\star}$ & & \\
\hline
\end{tabular}

Source: Authors' analysis

MR, mean returns; $\sigma$, standard deviation; $\Sigma_{\mu}$, semideviation with respect to the mean; $\beta$, beta against ALSI; $\beta_{\mu}^{D}$, downside beta with respect to the mean against $\mathrm{ALSI} ;{ }^{\star} p<.05, * \star p<.01, * \star \star p<.001$

\subsubsection{Cross sectional analysis}

More detailed results about the relationship between risk and return across companies can be obtained from regression analysis. The study runs a simple regression on unbalanced longitudinal panel data using fixed effects: this is a slight deviation from previous research. The deviation aims at more efficient estimates and increased accuracy of the relationships across time. The study runs a regression model relating mean returns to each of the four risk variables. More precisely, 


$$
M R_{i t}=\gamma_{0}+\gamma_{1} R V_{i t}+u_{i t}
$$

where $M R_{i t}$ and $R V_{i t}$ stand for mean return and risk variable respectively for company $i$ at time $t$, $\gamma_{0}$ and $\gamma_{1}$ are coefficients to be estimated; $u_{i t}$ is a composite error term which accounts for idiosyncratic error and an unobserved effect or factor which is constant across time for each company but is correlated to the risk variables.

It is assumed that factors within the companies may impact or bias the risk variables and/or mean returns and, as such, the fixed effects controls for this. The study assumes that certain factors such as industry, cost structure, corporate culture, target market are unique and time-invariant over the sample period and controlling for these allows more accurate measurement of the relationship between risk variables and mean returns. Each company is further assumed to be different and so $u_{i t}$ which measures individual characteristics should not be correlated across companies. A fixed effects model is applied and is supported by the results of a Hausman test which are not reported in this study. The key insight with the fixed effects would be that if the unobserved variable(s) does (d) not change over time, then any changes in the dependent variable must be due to influences other than these fixed characteristics.

Only heteroscedastic consistent results are reported in in TABLE 3 as the regressions display this weakness.

TABLE 3: Heteroscedasticity-consistent simple regression: risk variables

\begin{tabular}{|c|c|c|c|c|c|c|c|c|}
\hline & \multicolumn{2}{|c|}{$\boldsymbol{\beta}$} & \multicolumn{2}{|c|}{$\boldsymbol{\beta}_{\mu}^{D}$} & \multicolumn{2}{|c|}{$\sigma$} & \multicolumn{2}{|c|}{$\overline{\Sigma_{\mu}}$} \\
\hline & coef./t & s.e. & coef./t & s.e. & coef./t & s.e. & coef./t & s.e. \\
\hline \multirow[t]{2}{*}{$\gamma_{0}$} & $0.19^{\star \star \star}$ & 0.03 & 0.02 & 0.05 & 0.07 & 0.06 & $-0.17^{\star \star \star}$ & 0.04 \\
\hline & (7.23) & & $(0.46)$ & & $(1.21)$ & & $(-3.86)$ & \\
\hline \multirow[t]{2}{*}{$\gamma_{1}$} & $0.10^{\star}$ & 0.04 & $0.23^{\star \star \star}$ & 0.05 & $0.34^{\star \star}$ & 0.11 & $3.58^{\star \star \star}$ & 0.37 \\
\hline & (2.32) & & $(4.27)$ & & $(3.01)$ & & $(9.69)$ & \\
\hline F-stat & 5.4 & & 18 & & 9.1 & & 94 & 5.4 \\
\hline Prob $>F$ & 0.02 & & 0.00 & & 0.00 & & 0.00 & 0.02 \\
\hline $\mathrm{R}^{2}$ within & -0.05 & & -0.09 & & -0.26 & & -0.30 & -0.05 \\
\hline$R^{2}$ between & 0.01 & & 0.03 & & 0.08 & & 0.07 & 0.01 \\
\hline $\mathrm{R}^{2}$ overall & 0.09 & & 0.10 & & 0.19 & & 0.08 & 0.09 \\
\hline$\rho_{u_{i}, \gamma R V}$ & 0.02 & & 0.04 & & 0.10 & & 0.08 & \\
\hline$\rho_{u_{i t}, u_{i s}}$ & 0.23 & & 0.23 & & 0.24 & & 0.27 & \\
\hline
\end{tabular}

Source: Authors' analysis

$\sigma$, standard deviation; $\Sigma_{\mu}$, semideviation with respect to the mean; $\beta$, beta against ALSI; $\beta_{\mu}^{D}$, downside beta with respect to the mean against ALSI; t statistics in parentheses; s.e. - standard error corrected for heteroscedasticity

$\star p<.05, \star \star p<.01, * \star \star p<.001$ 
All the risk variables are clearly significant, however, their explanatory powers differ and are very weak. Focusing on the overall explanatory power, standard deviation explains the most (19\%) variation in returns, followed by downside beta which only explains $10 \%$.

The low explanatory powers can be due to several factors. Firstly, it may be due to the fact that the panel data measures explanatory power across multiple cross sections and so should not be taken as a weakness in the results. Another reason could be that the ALSI, the JSE's market portfolio, is not mean-variance efficient. According to Roll and Ross (1994) as cited by Estrada (2000), slight deviations of the market portfolio used to estimate betas may lead to no crosssectional correlation between betas and returns.

The last possible reason could be a result of model misspecification; relevant explanatory variables could have been omitted. The correlation between the fixed error term and the explanatory variable $\left(\rho_{u_{i} \gamma R V}\right)$ is very low. This correlation measures the effects of omitted variables. However, the correlation between error terms from one period to the next for a given company $\left(\rho_{u_{i t}, u_{i s}}\right)$ accounts for between $23-27 \%$ of the variation in returns. Thus factors which are unique to each company seem to account for a larger portion of the variation in returns, contributing to the low explanatory power of the risk variables. As the intercept $\left(\gamma_{0}\right)$ captures the effects of unobserved factors, a significant intercept provides further validity of the influence of idiosyncrasies on returns variation. The models with beta and semideviation have significant intercepts thus confirming that they leave room for unique company factors to influence returns. This is not the case for standard deviation and downside beta which explain most overall variation compared to beta and semideviation.

The report will next discuss the results of a bi-variate regression with standard deviation and beta against mean returns and the same is done with semi-deviation and downside beta. The tested equation is as follows:

$$
M R_{i t}=\gamma_{0}+\gamma_{1} R V_{1 i t}+\gamma_{2} R V_{2 i t}+u_{i t}
$$

where $R V_{1 i t}$ and $R V_{2 i t}$ stand for beta and standard deviation respectively under the MVB framework; and downside beta and semi-deviation under the MSB framework; $M R_{i t}$ is the mean return for company iat time $t, \gamma_{0}$ and $\gamma_{1}$ are coefficients to be estimated; $u_{i t}$ is a composite error term.

The results reported in TABLE 4 have been controlled for heteroscedasticity.

The results for the normal regressions (Panel A) and the heteroscedasticity controlled (Panel B) regressions are consistent. The MVB model and the MSB model are both significant. However, the MVB model explains $17 \%$ of the variation in mean returns, whereas the MSB model explains only $7 \%$. Once again unique factors explain about $26-28 \%$ of the variation in returns for both models.

Finally, a regression model is run where all the risk variables are included as explanatory variables. The model tested is

$$
M R_{i t}=\gamma_{0}+\gamma_{1} \beta_{i t}+\gamma_{2} \sigma_{2 i t}+\gamma_{3} \beta_{i t}^{D}+\gamma_{4} \Sigma_{\boldsymbol{\mu}}+u_{i t}
$$

where $\beta_{i t}, \sigma_{2 i t}, \beta_{i t}^{D}$ and $\Sigma_{\boldsymbol{\mu}}$ stand for beta, standard deviation, downside beta and semideviation respectively.; $M R_{i t}$ is the mean return for company $i$ at time $t, \gamma_{0}, \gamma_{1}, \gamma_{2}, \gamma_{3}$ and $\gamma_{4}$ are coefficients to be estimated; $u_{i t}$ is a composite error term. The results are presented in TABLE 5 . 
TABLE 5: Panel Data multiple Regression Results: MSB vs MVB risk variables

\begin{tabular}{|c|c|c|c|c|c|c|c|c|}
\hline & \multicolumn{4}{|c|}{$\begin{array}{c}\text { PanelA } \\
\text { Normal Regression }\end{array}$} & \multicolumn{4}{|c|}{$\begin{array}{c}\text { Panel B } \\
\text { Heteroscedasticity-consistent }\end{array}$} \\
\hline & $\boldsymbol{\beta} / \boldsymbol{\sigma}$ & & $\boldsymbol{\beta}_{\boldsymbol{\mu}}^{\boldsymbol{D}} / \Sigma_{\mu}$ & & $\beta / \sigma$ & & $\boldsymbol{\beta}_{\boldsymbol{\mu}}^{\boldsymbol{D}} / \Sigma_{\boldsymbol{\mu}}$ & \\
\hline & coef./t & s.e. & coef./t & s.e. & coef./t & s.e. & coef./t & s.e. \\
\hline \multirow[t]{2}{*}{$\gamma_{0}$} & $0.085^{\star \star \star}$ & 0.02 & $-0.152^{\star \star \star}$ & 0.03 & $0.085^{*}$ & 0.04 & $-0.152^{\star \star \star}$ & 0.04 \\
\hline & $(5.277)$ & & $(-4.877)$ & & $(2.023)$ & & $(-3.759)$ & \\
\hline \multirow[t]{2}{*}{$\gamma_{1}$} & $-0.168^{\star \star \star}$ & 0.02 & $-0.112^{\star \star}$ & 0.04 & $-0.168^{\star \star \star}$ & 0.04 & $-0.112^{\star}$ & 0.06 \\
\hline & $(-7.556)$ & & $(-2.882)$ & & $(-4.803)$ & & $(-1.972)$ & \\
\hline \multirow[t]{2}{*}{$\gamma_{2}$} & $0.517^{\star \star \star}$ & 0.03 & $4.405^{\star \star \star}$ & 0.38 & $0.517^{\star \star \star}$ & 0.10 & $4.405^{\star \star \star}$ & 0.66 \\
\hline & $(16.370)$ & & (11.657) & & $(5.352)$ & & $(6.702)$ & \\
\hline F-stat & 155 & & 110 & & 16.8 & & 49.3 & \\
\hline Prob $>F$ & 0.000 & & 0.000 & & 0.000 & & 0.000 & \\
\hline \multicolumn{9}{|l|}{$R^{2}$} \\
\hline within & -0.358 & & -0.308 & & -0.358 & & -0.308 & \\
\hline between & 0.098 & & 0.071 & & 0.098 & & 0.071 & \\
\hline overall & 0.171 & & 0.069 & & 0.171 & & 0.069 & \\
\hline$\rho_{u_{i}, \gamma R V}$ & 0.117 & & 0.079 & & 0.117 & & 0.079 & \\
\hline$\rho_{u_{i t}, u_{i s}}$ & 0.256 & & 0.276 & & 0.256 & & 0.276 & \\
\hline
\end{tabular}

Source: Authors' analysis

$\sigma$, standard deviation; $\Sigma_{\mu}$, semideviation with respect to the mean; $\beta$, beta against ALSI; $\beta_{\mu}^{D}$, downside beta with respect to the mean against ALSI; t statistics in parentheses; s.e. - standard error corrected for heteroscedasticity

$\star p<.05, * \star p<.01, * \star * p<.001$

The results highlight that when all the risk variables are considered together, only beta and standard deviation are significant. The model explains $13.7 \%$ of the variation. The variation explained by other factors not included in the model is about $11.3 \%$ which is significant given the explanatory power of the risk variables. 
TABLE 5: Panel Data Regression Results: All risk variables

\begin{tabular}{|c|c|c|}
\hline \multicolumn{3}{|c|}{ All Variables } \\
\hline & coef./t & s.e. \\
\hline \multirow[t]{2}{*}{$\gamma_{0}$} & -0.026 & 0.106 \\
\hline & $(-0.245)$ & \\
\hline \multirow[t]{2}{*}{$\gamma_{1}$} & $-0.169^{\star \star \star}$ & 0.048 \\
\hline & $(-3.502)$ & \\
\hline \multirow[t]{2}{*}{$\gamma_{2}$} & $0.414^{\star}$ & 0.207 \\
\hline & $(2.000)$ & \\
\hline \multirow[t]{2}{*}{$\gamma_{3}$} & -0.011 & 0.075 \\
\hline & $(-0.140)$ & \\
\hline \multirow[t]{2}{*}{$\gamma_{4}$} & 1.515 & 1.735 \\
\hline & $(0.873)$ & \\
\hline F-stat & 51.5 & \\
\hline Prob $>F$ & 0.000 & \\
\hline $\mathrm{R}^{2}$ within & -0.409 & \\
\hline$R^{2}$ between & 0.102 & \\
\hline $\mathrm{R}^{2}$ overall & 0.137 & \\
\hline$\rho_{u_{i}, \gamma R V}$ & 0.113 & \\
\hline$\rho_{u_{i t}, u_{i s}}$ & 0.276 & \\
\hline
\end{tabular}

Source: Authors' analysis

t-statistics in parentheses; s.e. - standard error corrected for heteroscedasticity

$\star p<.05, \star \star x<.01, \star \star \star x<.001$

It is worth noting further that the idiosyncratic characteristics account for $27.6 \%$ of variation in mean returns. The lack of significance of semideviation and downside beta may be due to the fact that returns distribution on the JSE is not extremely asymmetric. The bi-variate regression results give an indication that the downside risk variables underperformed the conventional risk variables with regards to explanatory power.

A brief summary will be presented at this point before comparing the implied cost of equity using the risk measures. The results that have been reported thus far establish that in the case of South African companies (1) All risk variables are significantly related to mean returns; (2) standard deviation followed by downside beta have the highest individual explanatory powers, $19 \%$ and $10 \%$ respectively; (3) idiosyncratic factors and other unaccounted for factors explain a large part (23-37\%) of variation in mean returns; (4) The MVB framework risk variables combined together have a greater explanatory power (17\%) than MSB risk variables (7\%) when combined together; (5) when all risk variables are combined only beta and standard deviation are significant. 
Therefore, the evidence suggests that beta and standard deviation are better for assessing risk than downside beta and semideviation.

\subsubsection{Risk measures and cost of equity}

As in Estrada's studies, this study will now turn its attention to the comparison of costs of equities based on the four risk variables. From the risk variables included in the study, four risk measures are considered. The risk measures are the ratio between each risk variable for a given company in a given year and the same variable for the ALSI in that same year. The risk measures are then used to estimate the required returns for each company. Therefore:

$$
\begin{gathered}
R M_{\bar{\sigma}, t}=\overline{\sigma_{t}} / \sigma_{A L S I, t} \quad \Rightarrow E\left(C E_{\bar{\sigma}, t}\right)=R_{f t}+E R P_{A L S I, t} \times R M_{\bar{\sigma}, i t} \\
R M_{\overline{\Sigma_{\mu}}, t}=\overline{\Sigma_{\mu, t}} / \Sigma_{\mu, A L S I, t} \quad \Rightarrow E\left(C E_{\overline{\bar{\nu}_{\mu}}, t}\right)=R_{f t}+E R P_{A L S I, t} \times R M_{\overline{\bar{\Sigma}_{\mu}}, t} \\
R M_{\bar{\beta} t}=\overline{\beta_{t}} / \beta_{A L S I, t}=\overline{\beta_{t}} \quad \Rightarrow E\left(C E_{\bar{\beta} t}\right)=R_{f t}+E R P_{A L S I, t} \times \overline{\beta_{t}} \\
R M_{\overline{\beta_{\mu}^{D}, t}}=\overline{\beta_{\mu, t}^{D}} / \beta_{\mu, A L S I, t}^{D}=\overline{\beta_{i t}^{D}} \Rightarrow E\left(C E_{\overline{\beta_{\mu}^{D}}, t}\right)=R_{f t}+E R P_{A L S I, t} \times \overline{\beta_{\mu, t}^{D}}
\end{gathered}
$$

where $C E_{t}$ denotes the average cost of equity at time $t, \bar{\sigma}_{t}, \bar{\Sigma}_{\mu, t}, \bar{\beta}_{t}$ and $\overline{\beta_{\mu, t}^{D}}$ denote average standard deviation, average semideviation with respect to the mean, average beta and average downside beta with respect to the mean at time $t, E R P_{t}$ is the equity risk premium measured over the preceding 108-year period at time $t$ and is reported in TABLE A-3; likewise $R_{f, t}$ which represents the risk free rate on a 10 year government bond at time $t$ is reported in the same table. Equations 12 and 13 represent the CAPM and DCAPM respectively.

Averaging the risk variables for a large sample is approximately equal to the standard deviation of an equally weighted portfolio. So the calculated required return for a given year is approximately equal to the required return on the equally weighted portfolio.

TABL 6 reports some interesting findings. The first 4 columns show the estimates of standard deviation, semideviation, beta and downside beta. The next four columns present the risk measures on the risk variables. The last 4 columns report the average cost of equity specifically, the last two columns report the cost of equity from the CAPM and the D-CAPM respectively.

The first finding is that the overall downside beta is about $56 \%$ greater than the overall beta. The differences across the sample years are as high as $143 \%$ in 2014 and as low as $10 \%$ in 2009 . Second, for any given time period, the average required returns are different across risk measures. The required return based on semideviation is always the largest followed by standard deviation, downside beta and then beta. This finding contradicts the findings that Estrada has reported in his various articles on downside risk.

The required return for the full sample using beta is almost half the required returns based on semideviation. This is consistent with the findings of Estrada (2002a). Further it is noted that the cost of equity based on the D-CAPM is 200 basis points higher than the cost of equity generated by the CAPM. The difference is 400 basis points in 2014. TABLE A-4 reports that the overall difference is 300 basis points when the government treasury bill is the benchmark risk free rate. 
TABLE 6: Risk measures and cost of equity

\begin{tabular}{ccccccccccccc}
\hline year & $\boldsymbol{\sigma}$ & $\Sigma_{\boldsymbol{\mu}}$ & $\boldsymbol{\beta}$ & $\boldsymbol{\beta}_{\boldsymbol{\mu}}^{\boldsymbol{D}}$ & $\boldsymbol{R} \boldsymbol{M}_{\boldsymbol{\sigma}}$ & $\boldsymbol{R M}_{\Sigma_{\boldsymbol{\mu}}}$ & $\boldsymbol{R} \boldsymbol{M}_{\boldsymbol{\beta}}$ & $\boldsymbol{R} \boldsymbol{M}_{\boldsymbol{\beta} \boldsymbol{\mu}}$ & $\boldsymbol{C} \boldsymbol{E}_{\boldsymbol{\sigma}}$ & $\boldsymbol{C E}_{\Sigma_{\boldsymbol{\mu}}}$ & $\boldsymbol{C} \boldsymbol{E}_{\boldsymbol{\beta}}$ & $\boldsymbol{C E}_{\boldsymbol{\beta} \boldsymbol{\mu}}^{\boldsymbol{D}}$ \\
\hline 1999 & $52 \%$ & $46 \%$ & 0.72 & 0.80 & 2.26 & 2.29 & 0.72 & 0.80 & $26 \%$ & $26 \%$ & $17 \%$ & $17 \%$ \\
\hline 2000 & $54 \%$ & $47 \%$ & 0.74 & 0.94 & 2.25 & 2.42 & 0.74 & 0.94 & $26 \%$ & $27 \%$ & $17 \%$ & $18 \%$ \\
\hline 2001 & $57 \%$ & $48 \%$ & 0.67 & 0.93 & 2.17 & 2.50 & 0.67 & 0.93 & $23 \%$ & $25 \%$ & $15 \%$ & $16 \%$ \\
\hline 2002 & $59 \%$ & $49 \%$ & 0.65 & 0.81 & 2.19 & 2.47 & 0.65 & 0.81 & $22 \%$ & $24 \%$ & $14 \%$ & $15 \%$ \\
\hline 2003 & $57 \%$ & $45 \%$ & 0.63 & 1.03 & 2.61 & 4.94 & 0.63 & 1.03 & $22 \%$ & $34 \%$ & $12 \%$ & $14 \%$ \\
\hline 2004 & $59 \%$ & $43 \%$ & 0.58 & 1.09 & 2.91 & 4.91 & 0.58 & 1.09 & $23 \%$ & $34 \%$ & $11 \%$ & $13 \%$ \\
\hline 2005 & $55 \%$ & $40 \%$ & 0.53 & 0.91 & 2.70 & 4.32 & 0.53 & 0.91 & $22 \%$ & $31 \%$ & $10 \%$ & $12 \%$ \\
\hline 2006 & $64 \%$ & $41 \%$ & 0.74 & 0.97 & 3.73 & 4.10 & 0.74 & 0.97 & $31 \%$ & $33 \%$ & $12 \%$ & $13 \%$ \\
\hline 2007 & $63 \%$ & $38 \%$ & 0.84 & 1.16 & 3.97 & 5.71 & 0.84 & 1.16 & $37 \%$ & $49 \%$ & $13 \%$ & $15 \%$ \\
\hline 2008 & $51 \%$ & $38 \%$ & 0.67 & 0.94 & 2.88 & 3.74 & 0.67 & 0.94 & $29 \%$ & $36 \%$ & $11 \%$ & $13 \%$ \\
\hline 2009 & $58 \%$ & $41 \%$ & 0.77 & 0.84 & 3.01 & 3.75 & 0.77 & 0.84 & $29 \%$ & $34 \%$ & $12 \%$ & $13 \%$ \\
\hline 2010 & $47 \%$ & $40 \%$ & 0.61 & 0.88 & 2.53 & 3.94 & 0.61 & 0.88 & $26 \%$ & $37 \%$ & $11 \%$ & $12 \%$ \\
\hline 2011 & $45 \%$ & $38 \%$ & 0.59 & 1.03 & 2.41 & 4.11 & 0.59 & 1.03 & $27 \%$ & $40 \%$ & $12 \%$ & $14 \%$ \\
\hline 2012 & $45 \%$ & $40 \%$ & 0.56 & 0.98 & 2.45 & 4.01 & 0.56 & 0.98 & $26 \%$ & $38 \%$ & $11 \%$ & $14 \%$ \\
\hline 2013 & $43 \%$ & $35 \%$ & 0.48 & 0.95 & 2.89 & 4.48 & 0.48 & 0.95 & $31 \%$ & $43 \%$ & $11 \%$ & $14 \%$ \\
\hline 2014 & $44 \%$ & $33 \%$ & 0.47 & 1.15 & 3.65 & 7.39 & 0.47 & 1.15 & $39 \%$ & $70 \%$ & $11 \%$ & $15 \%$ \\
\hline 111 & $52 \%$ & $12 \%$ & 0.62 & 0.97 & 2.85 & 4.31 & 0.62 & 0.97 & $28 \%$ & $39 \%$ & $12 \%$ & $14 \%$ \\
\hline
\end{tabular}

Source: Authors' analysis

$\sigma$, standard deviation; $\Sigma_{\mu}$, semideviation with respect to the mean; $\beta$, beta against ALSI; $\beta$, downside beta with respect to the mean against $A L S I$; RM, risk measure; $C \varepsilon$, cost of equity.

Estrada (2001) established that industries with high negative skewness had cost of equity based on downside risk higher than the cost of equity based on total risk. In addition to those findings, he reported that industries with higher positive skewness had cost of equity based on downside risk lower than cost of equity based on total risk. In TABLE A-1, with the exception of 1999, 2009 and 2012, all years, including the overall sample, are positively skew. This study establishes that the cost of equity based on semideviation is always higher than the cost of equity based on total risk which in turn is always higher than cost of equity based on downside beta.

The reported differences between the D-CAPM and the CAPM are huge. They can have a marked impact on the ability to accept a number of investment projects and can have a very significant impact on valuation. The evidence presented here has highlighted that the cost of equity using beta as the risk measure may be too low. However, this does not necessarily provide a clear backing to semideviation and downside beta as more appropriate measures of risk for South African companies but it does highlight that the differences cannot be ignored. 


\section{CONCLUSION}

A widely accepted measure of risk is important for the evaluation of projects and valuation of companies. The debate surrounding the most appropriate measure remains inconclusive and practitioners faced with low explanatory power of beta have turned to the CAPM. The measure of risk is of greater concern in emerging markets. Earlier researchers have challenged the validity of beta from both a theoretical and an empirical point of view. They have found support for downside risk variables such as semideviation and downside beta especially in markets which exhibit nonnormal and asymmetric returns like emerging markets.

The present work uses the mean returns of shares traded on the JSE Securities Exchange from 1999 to 2014 and investigates empirically the relationship between risk and return in an MVB framework (standard deviation and beta) and in an MSB framework (semideviation and downside beta). Semideviation and downside beta are considered plausible measures of risk as they capture downside risk that investors wish to avoid.

Empirical evidence reported elsewhere suggests that semideviation and downside beta explain the cross section of returns where beta fails. This evidence is much stronger for emerging markets. The evidence from this article, however, contradicts these findings. While the downside risk variables are significant explanatory variables when regressed against mean returns, they have weaker explanatory power compared to the normal risk variables.

The risk variables from the two opposing frameworks, however, share a common inherent weakness in that they explain a small portion of mean return variation (not more than $20 \%$ ) leaving other unobserved factors including company specific factors to explain the balance. This evidence weakens the support for downside risk measures as plausible risk measures in South Africa and suitable for emerging markets. However, it must be qualified that the assumptions under which the downside risk measures find favour, that is non-normal and asymmetric returns distributions, are slightly true from a graphical examination of mean returns in South African. This probably explains the unconvincing results reported on the downside risk variables in this study.

Finally, the D-CAPM generates average required returns which are higher than CAPM generated required returns by as much as 400 basis points. This would be expected to change the investing decision significantly and affect the valuation of companies. This difference is difficult to ignore even in the light of the CAPM proving to have a slight edge over D-CAPM in South Africa.

\section{LIST OF REFERENCES}

Abdalla, I. S., \& Murinde, V. (1997). Exchange rate and stock price interactions in emerging financial markets: evidence on India, Korea, Pakistan and the Philippines. Applied financial economics., 7(1), pp. 25-35.

Agiakloglou, C., \& Newbold, P. (1992). EMPIRICAL EVIDENCE ON DICKEY-FULLER-TYPE TESTS. Journal of Time Series Analysis, 13(6), pp. 471-483.

Aiko, R., \& Logan, C. (2014, March 5). Africa's Willing Taxpayers Thwarted by Opaque Tax Systems, Corruption. Retrieved May 10, 2014, from Afrobarometer:

http://www.afrobarometer.org/files/documents/policy_brief/ab_r5_policypaperno7.pdf 
Allingham, M. G., \& Sandmo, A. (1972, August). Income Tax Evasion: A Theoretical Analysis. Journal of Public Economics, 1, pp. 323-338.

Alm, J., \& Torgler, B. (2011). Do Ethics Matter? Tax Compliance and Morality. Journal of Busines Ethics, 101, pp. 635-651.

Alm, J., Jackson, B. R., \& McKee, M. (1992, March). Estimating the determinants of taxpayer compliance with experimental data. National Tax Journal, 45(1), pp. 107-114.

Alm, J., Kirchler, E., \& Muehlbacher, S. (2012, September). Combining Psychology and Economics in the Analysis of Compliance: From Enforcement to Cooperation. Economic Analysis \& Policy, 42(2), pp. 133-151.

Anderson, L. W., \& Krathwohl, D. R. (2001). A taxonomy for learning, teaching and assessing: A revision of Bloom's Taxonomy of educational objectives: Complete edition. New York: Longman.

Anderton, C., \& Carter, J. (2009). Principals of Conflict Economics A Primer for Social Science. New York: Cambridge University Press.

Aquastat. (2010). South Africa. (U. Nations, Producer, \& Food and Agriculturall Organisation of the United Nations) Retrieved from Aquastat:

www.fao.org/nr/water/aquastat/countries.../south_africa/index.stm

Ariely, D., Bracha, A., \& Meier, S. (2009). Doing Good or Doing Well? Image Motivation and Monetary Incentives in Behaving Prosocially. American Economic Review, 99(1), pp. 544-555.

Artavanis, N., Diacogiannis, G., \& Mylonakis, J. (2010, August). The D-CAPM: The Case of Great Britain and France. International Journal of Economics and Finance, 2(3), pp. 25-38.

Ashraf, N., Bohnet, I., \& Plankov, N. (2006). Decomposing Trust and Trustworthiness. Experimental Economics, 9, pp. 193-208.

Balliet, D., Mulder, L. b., \& Van Lange, P. A. (2011). Reward, Punishment, and Cooperation: A MetaAnalysis. Psychological Bulletin, 137(4), pp. 594-615.

Batrancea, L., \& Nichita, R. (2013). Tax Non-compliance Behavior in the Light of Tax Law Complexity and the Relationship Between Authorities and Taxpayers. Annals of the Alexandru loan Cuza University - Economics, 59(1), pp. 97-106.

Bawa, V. S., \& Lindenberg, E. B. (1977, November). Capital market equilibrium in a mean-lower partial moment framework. Journal of Financial Economics, 5(2), pp. 189-200.

Bazart, C., \& Pickhardt, M. (2009). Fighting Income Tax Evasion with Positive Rewards; Experimental Evidence. Montpellier: LAMETA.

Benk, S., \& Budak, T. (2012). Power and trust as determinants of voluntary versus enforced tax compliance: Empirical evidence for the slippery slope framework from Turkey. African Journal of Business Management, 6(4), pp. 1499-1505.

Ben-Ner, A., \& Halldorsson, F. (2010). Trusting and trustworthiness: What are they, how to measure them, and what affects them. Journal of Economic Psychology, 31, pp. 64-79. 
Bornman, M. (2014). Principles for understanding, encouraging and rewarding voluntary tax compliance. Department of Accountancy. Johannesburg: University of Johannesburg.

Bourdieu, P. (1985). The Market of Symbolic Goods. Poetics, 14, pp. 13-44.

Bowers, J., \& Robinson, P. H. (2012). Perceptions of Fairness and Justice: The shared Aims and 0ccasional Conflicts of Legitimacy and Moral Credibility. Wake Forest Law review, 47, pp. 211-284.

Braithwaite, V. (1995). Games of Engagement: Postures Within the Regulatory Community. Law \& Policy, 17(3), pp. 225-255.

Braithwaite, V. (2002). A New Approach to Tax Compliance. In V. Braithwaite, Taxing Democracy (pp. 1-11). Hants: Ashgate Publishing Ltd.

Braithwaite, V. (2002). Taxing Democracy. Aldershot: Ashgate Publishing Ltd.

Brixiová, Z., \& Ncube, M. (2014). The Real Exchange Rate and Growth in Zimbabwe: Does the Currency Regime Matter? IZA Discussion Papers, No. 8398, pp. 1-29.

Brogaard, J., Hendershott, T., \& Riordan, R. (2014). High-frequency trading and price discovery. Review of Financial Studies, 27(8), pp. 2267-2306.

Brooks, C. (2008). Introductory Econometrics for Finance (2nd ed.). New York: Cambridge University Press.

Brooks, C. (2008). Introductory Econometrics for Finance. New York: Cambridge University Press. Business Environment Specialists. (2013b). Understanding Women Entrepreneurs in South Africa. Retrieved June 10, 2014, from SBP: www.sbp.org.za

Caccioli, F., Shrestha, M., Moore, C., \& Farmer, J. D. (2014). Stability analysis of financial contagion due to overlapping portfolios. Journal of Banking \& Finance, 46, pp. 233-245.

Callihan, D. S., \& Spindle, R. M. (1997). An Examination of Contingent and Non-contingent rewards in a Tax Compliance Experiment. Advances in Taxation, 9, pp. 1-23.

Cao, G., Xu, L., \& Cao, J. (2012). Multifractal detrended cross-correlations between the Chinese exchange market and stock market. Physica A: Statistical Mechanics and its Applications, 391(20), pp. $4855-4866$.

Caporale, G. M., Hunter, J., \& Ali, F. M. (2014). On the linkages between stock prices and exchange rates: Evidence from the banking crisis of 2007-2010. International Review of Financial Analysis, 33, pp. $87-103$.

Carmines , દ. G., \& Zeller, R. A. (1979). Reliability and validity assessment. Retrieved September 02, 2014, from SAGE Research Methods: http://0-dx.doi.org.ujlink.uj.ac.za/10.4135/9781412985642

Cash Economy Task Force. (1998). Improving Tax Compliance in the Cash Economy, April 1998. Canberra: Australian Taxation Office.

Cash Economy Task Force. (2003). The Cash Economy under the New Tax System. Commonwealth of Australia. 
Castelfranchi, C., \& Falcone, R. (2001). Social trust: A Cognitive Approach. In C. Castelfranchi, \& T. Yao-Hua, Trust and Deception in Virtual Societies (pp. 55-90). Dordrecht: Springer Science+Business Media.

Cenedese, G., Payne, R., Sarno, L., \& Valente, G. (2014). What Do Stock Markets Tell Us About Exchange Rates? Available SSRN 2467707.

Chadwick, M., Highton, N., \& Palmer, J. (1985). Developing Coal in Developing Countries. Ambio, 14(4/5), pp. 249-252.

Chinn, M. D. (2006). Real exchange rates. New Palgrave Dictionary.

Chkili, W., \& Nguyen, D. K. (2014). Exchange rate movements and stock market returns in a regimeswitching environment: Evidence for BRICS countries. Research in International Business and Finance, 31, pp. 46-56.

Chu, S. (2010). Scaling up Clean Energy. Washington DC: Clean Energy Ministerial.

Colacito, R., \& Croce, M. M. (2011). Risks for the long-run and the real exchange rate. Journal of Political Economy, 119(1), pp. 1-33.

Combes, J. L., Kinda, T., \& Plane, P. (2012). Capital flows, exchange rate flexibility, and the real exchange rate. Journal of Macroeconomics, 34(4), pp. 1034-1043.

Corfee-Morlot, J., Maslin, M., \& Burgess, J. (2007). Global Warming in the Public Sphere. Philosophical Transactions: Mathematical, Physical and Engineering Sciences, 365(1860), pp. 2741-2776.

Cullis, J. G., \& Lewis, A. (1997). Why people pay taxes" From a conventional economic model to a model of social convention. Journal of Economic Psychology, 18, pp. 305-321.

Cwynar, W., \& Kazmierkiewicz , P. (2010). Is D-CAPM Superior to CAPM When Assessing Investment Risk on the Polish Stock Market? Retrieved October 29, 2014, from http://ssrn.com/abstract=1550684

De Cremer, D., \& Tyler, T. R. (2007). The Effects of Trust in Authority and Procedural Fairness on Cooperation. Journal of Applied Psychology, 92(3), pp. 639-649.

de Roon, F., Eiling, E., Gerard, B., \& Hillion, P. (2012, October 17). Currency Risk Hedging: No Free Lunch. Retrieved October 19, 2015, from SSRN: http://ssrn.com/abstract $=1343644$ or http://dx.doi.org/10.2139/ssrn.1343644

Deci, \&. L., Koestner, R., \& Ryan, R. M. (1999). A Meta-Analytic Review of Experiments Examining the Effects of Extrinsic Rewards on Intrinsic Motivation. Psychological Bulletin, 125(6), pp. 627-668.

DeJong, D. N., Nankervis, J. C., Savin, N. E., \& Whiteman, C. H. (1992). The power problems of unit root test in time series with autoregressive errors. Journal of Econometrics, 53(1), pp. 323-343.

Department of Energy. (2011, March). Integrated Resource Plan for Electricity 2010-2030. DoE.

Retrieved from www.energy.gov.za

Dickey, D. A., \& Fuller, W. A. (1981). Likelihood Ratio Statistics for Autoregressive Time Series with a Unit. Root. Econometrica, 49, pp. 1057-1072. 
Dornbusch, R. (1976). Expectations and Exchange Rate Dynamics. Journal of Political Economy, 84, pp. 1161-1176.

Dornbusch, R., \& Fischer, S. (. (1980). Exchange rates and the current account. The American Economic Review, pp. 960-971.

Duca, M. D., \& Fuscoe, J. (1966). Application of Advances in Space Technology to Water Resources Management. Water Pollution Control Federation, 38(6), pp. 976-989.

Duncan, R. (2001). World Energy Production, Population Growth, and the Road to the Olduvai Gorge. Population and Environment, 22(5), pp. 503-522.

Eberhardt, R., \& Pegram, G. (2000). The Water Sector, a position paper. WWF, Macroeconomic Reforms and Sustainability Development Project. Johannesburg: DBSA, Midrand in association with the Palmer Development Group.

Ehrmann, M., Fratzscher, M., \& Rigobon, R. (2011). Stocks, bonds, money markets and exchange rates: measuring international financial transmission. Journal of Applied Econometrics, 26(6), pp. 948-974.

EMM. (2013). Draft Annual Report. Boksburg: Ekurhuleni Metropolitan Municipality.

Enders, W. (2010). Applied Econometric Time Series, $3^{\text {td }}$ edition. USA: Wiley \& Sons, Inc.

Estrada, J. (2000, Fall). The Cost of Equity in Emerging Markets: A Downside Risk Approach. Emerging Markets Quarterly, 3(Fall), pp. 19-30.

Estrada, J. (2001, Spring). The Cost of Equity in Emerging Markets: A Downside Risk Approach (II). Emerging Markets Quarterly, 5(1), pp. 63-72.

Estrada, J. (2002a, IESE Working Paper No. D/491 IESE Working Paper No. D/491). The Cost of Equity of Internet Stocks: A Downside Risk Approach. Working Paper, IESE Business School, IESE Business School. doi:Working Paper

Estrada, J. (2002b). Systematic risk in emerging markets: the D-CAPM. Emerging Markets Review, 3(4), pp. 365-379.

Estrada, J. (2004, December). Mean-Semi Variance Behavior: An Alternative Behavioral Model. Journal of Emerging Market Finance, 3(3), pp. 231-248.

Fehr, E., \& Falk, A. (2002). Psychological Foundations of Incentives. Institute for the Study of Labor. Zurich: Center for Economic Studies \& Ifo Institute for Economic Research.

Feld, L. P., \& Frey, B. S. (2002). Trust Breeds Trust: How Taxpayers Are Treated. University of Zurich. Zurich: Institute for Empirical Research in Economics.

Feld, L. P., \& Frey, B. S. (2003, December). The Tax Authority and the Taxpayer: An Exploratory Analysis. Retrieved February 18, 2014, from Citeseer:

http://citeseerx.ist.psu.edu/viewdoc/download?doi=10.1.1.200.8641\&rep=repl\&type=pdf

Feld, L. P., \& Frey, B. S. (2007, January). Tax Compliance as the Result of a Psychological Tax Contract: The Role of Incentives and Responsive Regulation. Law \& Policy, 29(1), pp. 102-120. 
Feld, L. P., Frey, B. S., \& Torgler, B. (2006). Rewarding Honest Taxpayers? Evidence on the impact of rewards from field experiments. Basel: Centre for Research in Economica, Management and the Arts. Fjeldstad, 0.-H., Schulz-Herzenberg, C., \& Sjursen, I. H. (2012). Peoples' view of taxation in Africa: A review of research and determinants of tax compliance. CMI Working Paper 2012: 7, International Centre for Tax and Development.

Frankel, J. (1983). Monetary and portfolio balance models of exchange rate determination. (J. Bhandari, B. Putman, \& J. Levin, Eds.) Cambridge: MIT.

Frankel, J. (1986). Expectations and Commodity Price Dynamics: The Overshooting Model. American Journal of Agricultural Economics, 68, pp. 344-348.

Frankel, J. A. (1984). Tests of monetary and portfolio balance models of exchange rate determination. . In Exchange rate theory and practice (pp. 239-260). Chicago University Press. Freedman, D., Rothenburg, T., \& Sutch, R. (1983). On Energy Policy Models. Journal of Business \& Economic Statistics, 1(1), pp. 24-32.

Frey, B. S., \& Jegen, R. (2001). Motivation Crowding Theory. Journal of Economic Surveys, 15(5), pp. 589-611.

Frey, B. S., \& Torgler, B. (2004). Taxation and Conditional Cooperation. Basel: Centre for Research in Economics, Management and the Arts.

Frey, B., \& Holler, M. (1998). Tax Compliance Policy Reconsidered. Homo Oeconomicus, xv(1), 27-44. Friedman, L. (2010, June 2). New South African coal plant seeks emission credits for 'cleaner' coal function. New York Times.

Gay Jr, R. D. (2011). Effect of macroeconomic variables on stock market returns for four emerging economies: Brazil, Russia, India, and China. International Business \& Economics Research Journal, 7(3), pp. 1-8.

Grasmick, H. G., \& Scott, W. J. (1982). Tax Evasion and Mechanisms of Social Control: a Comparison with Grand and Petty Theft. Journal of Economic Psychology, 2, pp. 213-230.

Greyling, F. C. (2007). The why and how of technology-assisted learning: authentic professional development for higher education practitioners. Doctoral Desitation. Johannesburg: University of Johannseburg.

Harlow, W. V., \& Rao, R. K. (1989, September). Asset Pricing in a Generalized Mean-Lower Partial Moment Framework: Theory and Evidence. The Journal of Financial and puantitative Analysis, 24(3), pp. 285-311.

Hogan, W. W., \& Warren, J. M. (1974, January). Toward the Development of an Equilibrium CapitalMarket Model Based on Semivariance. The Journal of Financial and Quantitative Analysis, 9(1), pp. 111.

I-Net Bridge. (2011, September 26). AfDB, Eskom sign $\$ 365 \mathrm{~m}$ in loan pacts. Business Report. International Energy Forum. (2010). The Evolving Roles of International Organisations and the Private Sector in Energy Security and Sustainability. International Energy Forumn. 
Jefferis, K., \& Smith, G. (2004). Capitalisation and Weak-form Efficiency in the JSE Securities Exchange. South African Journal of Economics, 72, pp. 684-707.

Johansen, S. (1988). Statistical analysis of cointegration vectors. Journal of economic dynamics and control, 12(2), pp. 231-254.

Johansen, S., \& Juselius, K. (2001). Controlling inflation in a cointegrated vector autoregressive model with an application to US data. University of Copenhagen Dept. of Economics Discussion Paper, 01-03.

Jones, W. (2003, April). How Much Water Does it Take to Make Electricity. IEEE Spectrum.

Jongwanich, J., \& Kohpaiboon, A. (2013). Capital flows and real exchange rates in emerging Asian countries. Journal of Asian Economics, 24, pp. 138-146.

Jorion, P. (1991). The pricing of exchange rate risk in the stock market. Journal of Financial and Quantitative Analysis, 26(3), pp. 363-376.

Kastlunger, B., Lozza, E., Kirchler, E., \& Schabmann, A. (2013). Powerful authorities and trusting citizens: The Slippery Slope Framework and tax compliance in Italy. Journal of Economic Psychology, 34, pp. 36-45.

Kastlunger, B., Muehlbacher, S., Kirchler, E., \& Mittone, L. (2011). What Goes Around Comes Around? Experimental Evidence of the Effect of Rewards on Tax Compliance. Public Finance Review, 39(1), pp. $150-167$.

Kirchler, E. (2007). The Economic Psychology of Tax Behaviour. New York: Cambridge University Press.

Kirchler, E., \& Wahl, I. (2010). Tax compliance inventory TAX-I: Designing an inventory for surveys of tax compliance. Journal of Economic Psychology, 31, pp. 331-346.

Kirchler, E., Hoelzl, E., \& Wahl, I. (2007). Enforced versus Voluntary Tax Compliance: The Slippery Slope Framework. Journal of Economic Psychology, pp. 210-225.

Kirchler, E., Hofmann, E., \& Gangl, K. (2012). From Mistrusting Taxpayers to Trusting Citizens Empirical Evidence and Further Development of the Slippery Slope Framework. Economic psychology in the modern world: collected papers, pp. pp. 125-146.

Kirchler, E., Muehlbacher, S., Kastlunger, B., \& Wahl, I. (2007). Why Pay Taxes? A Review of Tax Compliance Decisions. Andrew Young School of Policy Studies, International Studies Program. Atlanta: Georgia State University.

Kirchler, E., Niemirowski, A., \& Wearing, A. (2006). Shared subjective views, intent to cooperate and tax compliance: Similarities between Australian taxpayers and tax officers. Journal of Economic Psychology, 27, pp. 502-517.

Kisaka, S. E., \& \& Mwasaru, A. (2012). The causal relationship between exchange rates and stock prices in Kenya. Research Journal of Finance and Accounting, 3(7), pp. 121-130.

Kochler, C., Batrancea, L., Nichita, A., Pantya, J., Belianin, A., \& Kirchler, દ. (2013). Trust and power as determinants of tax compliance: Testing the assumptions of the slippery slope framework in Austria, Hungary, Romania and Russia. Journal of Economic Psychology, 34, pp. 169-180. 
Kornhauser, M. (2007). Normative and cognitive aspects of tax compliance: Literature review and recommendation for the IRS regarding individual taxpayers. New York: IRS.

Krämer, W. (1998). Fractional integration and the augmented Dickey-Fuller test. Economics Letters, 61(3), pp. 269-272.

Kumar, C. (2003). Fresh Water Resources: A Perspective. India: National Institute of Hydrology.

Kunz, J., \& Linder, S. (2012). Organizational Control and Work Effort - Another Look at the Interplay of Rewards and Motivation. European Accounting Review, 21(3), pp. 591-621.

Lacetera, N., \& Macis, M. (2010). Do all material incentives for pro-social activities backfire? The response to cash and non-cash incentives for blood donations. Journal of Economic Psychology, 31 , pp. 738-748.

Langham, J., Paulsen, N., \& Hartel, C. દ. (2012). Improving tax compliance strategies: can the theory of planned behavior predict business compliance. efournal of Tax Research, 10(2), pp. 364-402.

Leedy, P. D., \& Ormrod, J. E. (2010). Practical Research: Planning and Design, $9^{\text {th }}$ edition. Boston: Pearson Education, Inc.

Lemoine, J., \& Roland-Levy, C. (2013). Are taxpayers, who pay their taxes, all cooperative citizens? Citizenship Teaching \& Learning, 8(2), pp. 195-213.

Leventhal, G. (1980). What should be done with equity theory? New approaches to the study of fairness in social relationships. In K. Gergen, M. Greenberg, \& R. Willis, Social Exchange: Advances in theory and research (pp. 27-55). Neork: Plenum.

Levi, M., Tyler, T., \& Sacks, A. (2008). The Reasons for Compliance with Law. Yale University. Sydney: US Studies Centre.

Levy, H., \& Markowitz, H. (1979, June). Approximating Expectedd Utility by a Function of Mean and Variance. The American Economic Review, 69(3), pp. 308-317.

Liang, C. C., Chen, M. Y., \& Yang, C. H. (2015). The Interactions of Stock Prices and Exchange Rates in the ASEAN-5 Countries: New Evidence Using a Bootstrap Panel Granger Causality Approach. Global Economic Review, D0l:10.1080/1226508X.2015.1035300 (Published online: 24 Apr 2015), pp. 1-11.

Lin, C. H. (2012). The comovement between exchange rates and stock prices in the Asian emerging markets. International Review of Economics \& Finance, 22(1), pp. 161-17.

Lund, T. (2011, March). Power mad: Governmnets Tilt at an Energy Plan. FIN Week, pp. 15-18.

Mamoghlia, C., \& Daboussi, S. (2008). Valuation of hedge funds portfolios in a downside risk framework. Retrieved July 31, 2013, from http://ssrn.com/abstract $=1194282$

Mamoghlia, C., \& Daboussi, S. (2010). Capital Asset Pricing Models and Performance Measures in the Downside Risk Framework. Journal of Emerging Market Finance, 9, pp. 95-130.

Markowitz, H. (1952, March). Portfolio Selection. The Journal of Finance, 7(1), pp. 77-91.

Markowitz, H. (1959). Portfolio Selection: Efficient Diversification of Investments, $2^{\text {nd }}$ edition. (B.

Blackwell, Ed.) New York: Wiley, Yale University Press. 
Markowitz, H. (1991). Foundations of Portfolio Theory. Journal of Finance, 46, pp. 469-477.

Martin, S., \& Dolan, P. (2010, December 14). Dear Taxpayer, Congratulations! You've Won Your Money Back. Retrieved May 11, 2014, from Harvard Business Review Blog Network:

http://blogs.hbr.org/2010/12/dear-mr-taxpayer-congratulatio/

Meyer, W. N. (2007). The Economics of Water (First ed.). Pretoria: Van Schaik Publishers.

Moore, T., \& Wang, P. (2014). Dynamic linkage between real exchange rates and stock prices: Evidence from developed and emerging Asian markets. International Review of Economics \& Finance, 39, pp. 111.

Moosa, V. (2007). Climate Change Information sheet. Johannesburg: Eskom.

Muelbacher, S., Kirchler, E., \& Schwarzenberger, H. (2011). Voluntary versus enforced tax compliance: empirical evidence fro the "slippery slope" framework. European Journal of Law and Economics, 32, pp. 89-97.

Muhammad, N., Rasheed, A., \& Husain, F. (2002). Stock Prices and Exchange Rates: Are they Related? Evidence from South Asian Countries. The Pakistan Development Review, 4l(4), pp. 535-550.

Murdock Jr, B. B. (2014). Convolution and correlation in perception and memory. Perspectives on Learning and Memory(105).

Murphy, K. (2004). The Role of Trust in Nurturing Compliance: A Study of Accused Tax Avoiders. Law and Human Behavior, 28(2), pp. 187-209.

Murphy, K. (2005). Regulating More Effectively: The Relationship between Procedural Justice, Legitimacy, and Tax Non-compliance. Journal of Law and Society, 32(4), pp. 562-589.

Mutengezanwa, M., Mauchi, F. N., Njanike, K., Matanga, J., \& Gopo, R. N. (2012). The possibility of reintroducing the Zimbabwean dollar. Australian Journal of Business and Management Research, 2(6), pp. 1-8.

Nakunyada, W., \& Chikoko, L. (2013). The competitiveness of Zimbabwe's exports to South Africa during the recovery period 2009 to 2011. Journal of Economic and Financial Sciences, 6(3), pp. 645660 .

National Taxpayer Advocate. (2010). Annual Report to Congress. Washington D.C.: IRS.

Nikoomaram, H. (2010, November). Comparative analysis of sensitivity coefficient using traditional beta of CAPM and downside beta of D-CAPM in automobile manufacturing companies. African Journal of Business Management, 4(15), pp. 3289-3295.

0ECD. (2009). Managing and Improving Compliance: Recent Developments in Compliance Risk Treatments. Forum on Tax Administration: Compliance Sub-group. Centre for Tax Policy and Administration.

Organisation for Economic Co-operation and Development. (2010, November). Understanding and Influencing Taxpayers' Compliance Behaviour. Retrieved October 23, 2012, from 0عCD: http://www.oecd.org/tax/administration/46274793.pdf 
Pickhardt, M., \& Prinz, A. (2014). Behavioral dynamics of tax evasion - A survey. Journal of Economic Psychology, 40, pp. 1-19.

Pindiriri, C. (2012). Monetary Reforms and Inflation Dynamics in Zimbabwe. International Research Journal of Finance and Economics(90), pp. 207-222.

Prinz, A., Muehlbacher, S., \& Kirchler, દ. (2014). The slippery slope framework on tax compliance: An attempt to formalisation. Journal of Economic Psychology, 40, pp. $20-34$.

Quantec. (2010). Electricity generation and consumption: Eskom: Electricity produced - Gigawatthours. EasyXL. Johannesburg: StatsSA, P4141. Retrieved from www.quantec.com

Raei, R., Ahmadinia, H., \& Hasbaei, A. (2011, October). A Study on Developing of Asset Pricing Models. International Business Research, 4(4), pp. 139-152.

Ravenga, C., Brunner, J., Henninger, N., Kassem, K., \& Payne, R. (2000). Pilot Analysis of Global Ecosystems: Wetland Ecosystems. Washington, D.C.: World Resource Institute.

Ruiu, G., \& Lisi, G. (2011). Tax Morale, Slippery-Slope Framework and Tax Compliance: A Cross-section Analysis. Dipartimento di Scienze Economiche. Cassino (FR): Università degli Studi di Cassino.

Rusvingo, S. (2014). Declien in business activity on the Zimbabwe Stock Exchange. A sign of a bloodpath on the Zimbabwean economy. Global Journal of Management and Business Research, 14(9), pp. 32-38.

Ryan, R. M., \& Deci, દ. L. (2000). Intrinsic and Extrinsic Motivations: Classic Definitions and New Directions. Contemporary Educational Psychology, 25, pp. 54-67.

SARS. (2012a, April). Compliance Program (2012-2016).

Schmölders, G. (1959). Fiscal Psychology: A new Branch of Public Finance. National Tax Journal, 12(4), pp. 340-345.

Shapiro, A. (2010). Multinational Financial Management (9th ed.). Asia: John Wiley \& Sons, Inc.

Sharpe, W. (1964). Capital asset prices: A theory of market equilibrium under conditions of risk. Journal of Finance, 19(3), pp. 425-442.

Sibanda, M., \& Holden, M. (2013). Stock market development and economic growth in the SADC region: Evidence fromseven selected countries. PULA: Botswana Journal of African Studies, 27(49), pp. 292-307.

Slemrod, J. (1998, September). On Voluntary Compliance, Voluntary Taxes and Social Capital. National Tax Journal, 51(3), pp. 485-491.

Smith, L. (2005). South Africa: testing the waters of Private-Public parnerships. Amsterdam: Transnational Institute (NI) and Corporate Europe Observatory.

Smulders, S., \& Naidoo, G. (2013). Addressing The Small Business Tax Compliance Burden - Evidence from South Africa. Journal of Economic and Finacial Sciences, 6(1), pp. 33-53.

South African Reserve Bank. (2015, June 3). South African Reserve Bank. Retrieved from South African Reserve Bank: https://www.resbank.co.za/ 
South African Reserve Bank. (2015, June 3). South African Reserve Bank. Retrieved from https://www.resbank.co.za/

Sovacool, B. (2007). Coal and Nuclear Technologies: Creating a False Dichotomy for American Energy Policy. Policy Sciences, 40(2), pp. 101-122.

Taylor, N. (2002). Understanding Taxpayer Attitudes Through Understanding Taxpayer Identities. In V. Braithwaite, Taxing Democracy (pp. 71-92). Aldershot: Ashgate.

The Commonwealth Association of Tax Administrators. (2006). Tax Evasion and Avoidance: Strategies and Initiatives used by CATA Member Countries. Hampshire: Commonwealth Secretariate.

Tiwari, A. K., Bhanja, N., Dar, A. B., \& Islam, F. (2015). Time-frequency relationship between share prices and exchange rates in India: Evidence from continuous wavelets. Empirical Economics, 48, pp. 699-714.

Torgler, B. (2003). Beyond Punishment: A Tax Compliance Experiment with taxpayers in Costa Rica. Revista de Analisis Economico, 18(1), pp. 27-56.

Torgler, B. (2003, July). TAX MORALE: THEORY AND EMPIRICAL ANALYSIS OF TAX COMPLIANCE. Doctoral thesis. Basel: Universitat Basel.

Torgler, B. (2004). Tax Morale, Trust and Corruption: Empirical Evidence from Transition Countries. Basel: Center for Research in Economics, Management and the Arts.

Torgler, B., \& Schaffner, M. (2007, November). Causes and Consequences of Tax Morale: An Empirical Investigation. Crema Working Paper no 2007-11. Basel, Switzerland: Center for Research in Economics, Management and the Arts.

Tsagkanos, A., \& Siriopoulos, C. (2013). A long-run relationship between stock price index and exchange rate: a structural nonparametric cointegrating regression approach. Journal of International Financial Markets, Institutions and Money, 25, pp. 106-118.

Turner, J. (2005). Explaining the nature of power: A three-process theory. European Journal of Social Psychology, 35, pp. 1-22.

Tyler, T. (1990). Why People Obey the Law. Chelsea, Michigan: Yale University Press.

Tyler, T. (2006b). Restorative Justice and Procedural Justice: Dealing with Rule Breaking. Journal of Social Issues, 62(2), pp. 307-326.

Tyler, T. R. (2006a). Why People Obey the Law. Princeton, New Jersey: Princeton University Press.

Van den Bos, K., Wilke, H. A., \& Lind, દ. A. (1998). When Do We Need Procedural Fairness? The Role of Trust in Authority. Journal of Personality and Social Psychology, 75(6), pp. 1449-1458.

Van Dijke, M., \& Verboon, P. (2010). Trust in authorities as a boundary condition to procedural fairness. Journal of Economic Psychology, 31, pp. 80-91.

Verboon, P., \& Van Dijke, M. (2011). Whne do severe sanctions enhance compliance? The role of procedural fairness. Journal of Economic Psychology, 32, pp. 120-130. 
Wahl, I., Kastlunger, B., \& Kirchler, દ. (2010, October). Trust in Authorities and Power to Enforce Tax Compliance: An empirical Analysis of the "Slippery Slope Framework". Law \& Policy, 32(4), pp. 383406.

Welch, L. (1974). Lower bounds on the maximum cross correlation of signals . IEعE Transactions on Information theory, pp. 397-399.

Wenzel, M. (2002). Tax Compliance and the Psychology of Justice: Mapping the Field. In V. Braithwaite, Taxing Democracy (pp. 41-70). Aldershot: Ashgate.

Wenzel, M. (2004). An analysis of norm processes in tax compliance. Journal of Economic Psychology, 25, pp. 213-228.

WorldBank. (2010). World DataBank. World Development Indicators (WDI) \& Global Development Finance (GDF). Washington DC: World Bank. Retrieved from http://databank.worldbank.org/ddp/home.do

Worthington, A. C., \& Higgs, H. (2004). Art as an investment: Risk, return and portfolio diversification in major painting markets. Accounting and Finance, 44(2), pp. 257-271.

Zimbabwe Stock Exchange. (2013). http://www.zimbabwe-stock-exchange.com/about/about-us/. Retrieved June 03 , 2015, from http://www.zimbabwe-stock-exchange.com/about/about-us/ 
Okyere-Boakye \& O'Malley

\section{APPENDIX}

TABLE A-1: Analysis of mean returns skewness and kurtosis

\begin{tabular}{cccccc}
\hline Year & obs & mean & s.d. & skew & kurt \\
\hline 1999 & 113 & 0.50 & 0.49 & $(0.48)$ & 4.72 \\
2000 & 124 & 0.08 & 0.58 & 2.46 & 20.33 \\
2001 & 135 & 0.28 & 0.42 & 0.40 & 3.21 \\
2002 & 145 & 0.30 & 0.51 & 1.15 & 6.83 \\
2003 & 166 & 0.38 & 0.60 & 1.59 & 14.56 \\
2004 & 174 & 0.47 & 0.66 & 2.19 & 12.80 \\
2005 & 183 & 0.55 & 0.50 & 1.59 & 8.46 \\
2006 & 188 & 0.37 & 0.42 & 1.52 & 7.39 \\
2007 & 194 & 0.16 & 0.57 & 3.08 & 17.27 \\
2008 & 198 & $(0.18)$ & 0.56 & 2.64 & 30.47 \\
2009 & 205 & 0.24 & 0.42 & $(1.49)$ & 8.40 \\
2010 & 218 & 0.25 & 0.42 & 1.67 & 13.46 \\
\hline 2011 & 240 & 0.11 & 0.37 & 0.86 & 7.10 \\
2012 & 279 & 0.13 & 0.46 & $(0.13)$ & 8.25 \\
2013 & 289 & 0.17 & 0.50 & 0.99 & 8.14 \\
2014 & 291 & 0.14 & 0.54 & 1.57 & 17.89 \\
All & 3142 & 0.23 & 0.53 & 1.34 & 12.88 \\
\hline
\end{tabular}

Source: Authors' analysis

obs: no. of company years; mean: arithmetic mean of returns; s.d. : standard deviation; skew: skewness; kurt: kurtosis 


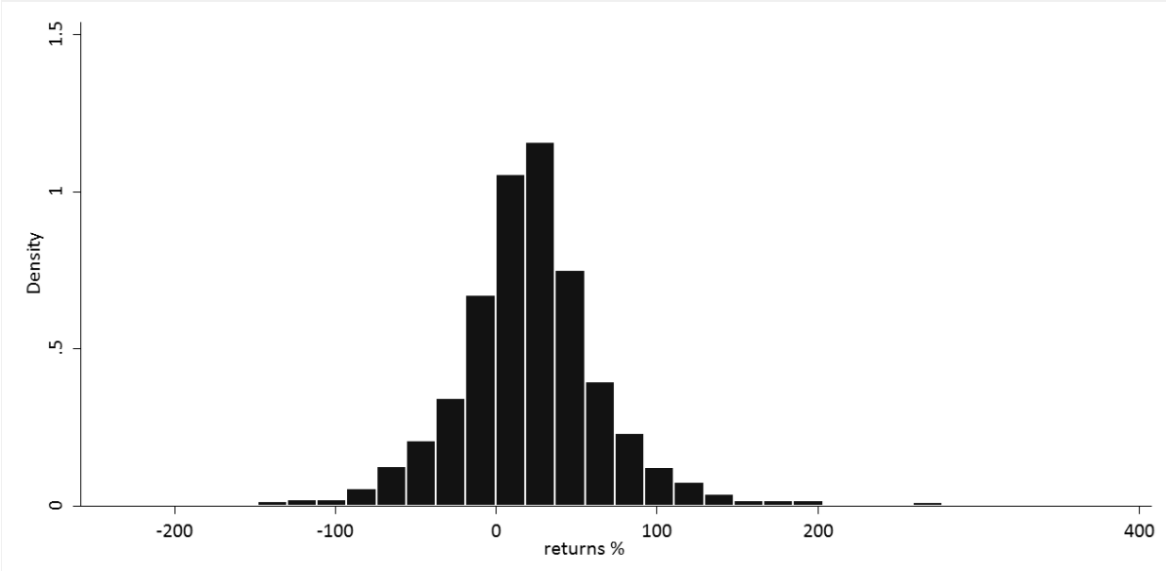

FIGURE A-1: Histogram of annualised cross-sectional returns (1999-2014) 
Okyere-Boakye \& O'Malley

TABLE A-2: Descriptive statistics (monthly returns)

\begin{tabular}{|c|c|c|c|c|c|c|c|}
\hline \multicolumn{8}{|l|}{ Panel $A$} \\
\hline & \multicolumn{4}{|c|}{ Within } & & \multicolumn{2}{|c|}{ Between } \\
\hline & s.d. & $\min$ & $\max$ & & s.d. & $\min$ & $\max$ \\
\hline returns & 38.84 & (14.16) & 1.21 & & 13.63 & $(1.24)$ & 0.85 \\
\hline beta & 17.96 & $(12.80)$ & 0.80 & & 14.08 & $(1.49)$ & 0.96 \\
\hline dbeta & 16.51 & $(8.82)$ & 1.08 & & 12.46 & 0.39 & 1.56 \\
\hline stddev & 10.41 & (11.45) & 0.57 & & 12.82 & 0.07 & 0.79 \\
\hline semidev & 0.48 & $(0.12)$ & 0.02 & & 0.25 & 0.01 & 0.03 \\
\hline \multicolumn{8}{|l|}{ Panel B } \\
\hline \multicolumn{8}{|c|}{ Overall } \\
\hline & s.d. & $\min$ & $\max$ & mean & $\mathrm{T}$ & groups & obs \\
\hline returns & 52.19 & $(2.41)$ & 1.40 & 0.28 & 10.14 & 311 & 3152 \\
\hline beta & 31.41 & $(4.15)$ & 1.15 & 0.63 & 10.14 & 311 & 3152 \\
\hline dbeta & 26.76 & 0.08 & 1.60 & 2.21 & 10.14 & 311 & 3152 \\
\hline stddev & 22.70 & 0.06 & 0.91 & 0.53 & 10.14 & 311 & 3152 \\
\hline semidev & 0.56 & 0.00 & 0.03 & 0.06 & 10.14 & 311 & 3152 \\
\hline
\end{tabular}

Source: Authors' analysis

s.d. : standard deviation; min: minimum; max: maximum; mean: arithmetic mean; T: average years per company; groups: no. of companies; obs: no. of company years 
TABLE A-3: Risk free rates and Equity risk premiums

\begin{tabular}{|c|c|c|c|c|c|}
\hline & \multicolumn{2}{|c|}{ Risk Free Rate } & \multicolumn{3}{|c|}{ Equity Risk Premium } \\
\hline & 10 year & 3 Month & 108 years & 78 years & 78 years \\
\hline & Gov bond & T-bill & (JSE-10y Gov) & (JSE-10Y Gov) & (JSE-3MTBill) \\
\hline 1999 & $13.68 \%$ & $12.94 \%$ & $4.45 \%$ & $5.26 \%$ & $5.76 \%$ \\
\hline 2000 & $12.72 \%$ & $10.09 \%$ & $5.28 \%$ & $5.79 \%$ & $6.58 \%$ \\
\hline 2001 & $11.49 \%$ & $9.69 \%$ & $5.33 \%$ & $5.29 \%$ & $6.19 \%$ \\
\hline 2002 & $10.51 \%$ & $11.08 \%$ & $5.40 \%$ & $5.36 \%$ & $6.34 \%$ \\
\hline 2003 & $9.02 \%$ & $10.92 \%$ & $4.98 \%$ & $5.08 \%$ & $6.24 \%$ \\
\hline 2004 & $8.18 \%$ & $7.60 \%$ & $4.83 \%$ & $5.19 \%$ & $6.52 \%$ \\
\hline 2005 & $7.44 \%$ & $6.89 \%$ & $4.86 \%$ & $5.47 \%$ & $6.90 \%$ \\
\hline 2006 & $7.84 \%$ & $7.33 \%$ & $5.10 \%$ & $6.10 \%$ & $7.65 \%$ \\
\hline 2007 & $8.50 \%$ & $9.00 \%$ & $5.41 \%$ & $7.14 \%$ & $8.68 \%$ \\
\hline 2008 & $7.21 \%$ & $10.72 \%$ & $5.65 \%$ & $7.60 \%$ & $8.98 \%$ \\
\hline 2009 & $8.40 \%$ & $8.17 \%$ & $5.25 \%$ & $6.74 \%$ & $8.17 \%$ \\
\hline 2010 & $7.31 \%$ & $6.48 \%$ & $5.80 \%$ & $7.53 \%$ & $8.82 \%$ \\
\hline 2011 & $7.94 \%$ & $5.51 \%$ & $6.11 \%$ & $7.77 \%$ & $9.23 \%$ \\
\hline 2012 & $7.29 \%$ & $5.27 \%$ & $6.44 \%$ & $7.77 \%$ & $9.15 \%$ \\
\hline 2013 & $8.23 \%$ & $5.31 \%$ & $5.58 \%$ & $7.85 \%$ & $9.41 \%$ \\
\hline 2014 & $8.59 \%$ & $5.88 \%$ & $5.71 \%$ & $8.34 \%$ & $9.79 \%$ \\
\hline
\end{tabular}

Source: Authors' analysis 
Okyere-Boakye \& O'Malley

TABLE A-4: Risk measures and cost of equity (risk free rate $\mathbf{3}$ month treasury bills)

\begin{tabular}{|c|c|c|c|c|}
\hline year & $C E_{\sigma}$ & $C E_{\Sigma}$ & $C E_{\beta}$ & $C E_{\beta^{D}}$ \\
\hline 1999 & $26 \%$ & $26 \%$ & $17 \%$ & $18 \%$ \\
\hline 2000 & $25 \%$ & $26 \%$ & $15 \%$ & $16 \%$ \\
\hline 2001 & $23 \%$ & $25 \%$ & $14 \%$ & $15 \%$ \\
\hline 2002 & $25 \%$ & $27 \%$ & $15 \%$ & $16 \%$ \\
\hline 2003 & $27 \%$ & $42 \%$ & $15 \%$ & $17 \%$ \\
\hline 2004 & $27 \%$ & $40 \%$ & $11 \%$ & $15 \%$ \\
\hline 2005 & $26 \%$ & $37 \%$ & $11 \%$ & $13 \%$ \\
\hline 2006 & $36 \%$ & $39 \%$ & $13 \%$ & $15 \%$ \\
\hline 2007 & $43 \%$ & $59 \%$ & $16 \%$ & $19 \%$ \\
\hline 2008 & $37 \%$ & $44 \%$ & $17 \%$ & $19 \%$ \\
\hline 2009 & $33 \%$ & $39 \%$ & $14 \%$ & $15 \%$ \\
\hline 2010 & $29 \%$ & $41 \%$ & $12 \%$ & $14 \%$ \\
\hline 2011 & $28 \%$ & $43 \%$ & $11 \%$ & $15 \%$ \\
\hline 2012 & $28 \%$ & $42 \%$ & $10 \%$ & $14 \%$ \\
\hline 2013 & $33 \%$ & $47 \%$ & $10 \%$ & $14 \%$ \\
\hline 2014 & $42 \%$ & $78 \%$ & $10 \%$ & $17 \%$ \\
\hline All & $31 \%$ & $44 \%$ & $13 \%$ & $16 \%$ \\
\hline
\end{tabular}

Source: Authors' analysis 